\title{
A NEMZETKÖZI BÜNTETŐBÍRÓSÁG JOGHATÓSÁGA AZ ÁLLAMFÖI IMMUNITÁS TÜKRÉBEN - KÜLÖNÖS TEKINTETTEL AZ AL BASHIR ESETRE
}

The jurisdiction of the International Criminal Court in relation to head of state immunity - In particular, the Case of Al Bashir

\section{Pesci $\mathrm{Marco}^{1}$}

\begin{abstract}
Absztrakt: Az államfői immunitás kérdése a nemzetközi büntetőjog egyik legfontosabb területe, hiszen a nemzetközi bűncselekmények elkövetői gyakorta az állami hierarchia csúcsán helyezkednek el. Ebből kifolyólag hivatali idejük alatt főszabály szerint nincs lehetőség az általuk véghezvitt cselekmények büntetőjogi szempontból történő elbírálására. Ezt a problémát felismerve a Nürnbergi Törvényszéktől kezdve, az Egyesült Nemzetek Szervezetének keretében felállított ad-hoc törvényszékek továbbá a Nemzetközi Büntetőbíróság Statútuma is expressis verbis rögzítik a hivatalos minőség irrelevanciáját. Ugyanakkor látnunk kell azt is, hogy a jelenleg hatályos nemzetközi közjog normarendszere alapján főszabály szerint nem állapítható meg kötelezettség egy olyan államra nézve, amely nem részese az adott szerződésnek. Tekintettel arra, hogy a Nemzetközi Büntetôbíróságnak önálló erőszakszervezete nincs a tagállamok együttmúködésére van utalva a letartóztatási parancsok foganatosításának tekintetében. Ebből kifolyólag kérdésként merül fel, hogy vajon mit tehet a Nemzetközi Büntetôbíróság amennyiben egy olyan állam hivatalban lévő államföjével szemben kíván eljárást folytatni, amely nem ratifikálta a Római Statútumot? Ezzel a problémával szembesült Omar Hassan Ahmad Al Bashir esetében, amelynek leltároztatását számos tagállam megtagadta az őt megillető államfői immunitásból adódóan. Jelen írás keretében a vonatkozó esetjogon
\end{abstract}

\footnotetext{
${ }^{1}$ Debreceni Egyetem Márton Géza Állam és Jogtudományi Doktori Iskola Doktorandusz Hallgatója, a Külgazdasági és Külügyminisztérium Nemzetközi Jogi Főosztályának jogi referense. E-mail: marcopesci94@gmail.com Jelen tanulmányt a szerző kutatói minőségben készítette és az nem tekinthető a Külgazdasági és Külügyminisztérium hivatalos álláspontjának.

A szerző további munkásságát lásd a Magyar Tudományos Művek Tára oldalán: https: $/ / \mathrm{m} 2 . \mathrm{mtmt}$.hu/gui $2 /$ ?type $=$ authors\&mode $=$ browse\&sel $=10069871$
} 
keresztül mutatom be a kortárs nemzetközi büntetőjog korlátait és teszek kísérletet egy megoldási javaslatra.

Kulcsszavak: Al Bashir, Nemzetközi Büntetőbíróság, Római Statútum, 27. cikk, 98. cikk, Szudán, Dárfúr, Államfői immunitás, ENSZ BT, együttmûködési kötelezettség, UNSC RES 1593

Abstract: The issue of head of state immunity is one of the most intriguing questions of international criminal law since the perpetrators of international crimes are usually located at the top of state hierarchy. As of consequence, they can not be prosecuted for their actions during their time in office. In order to avoid such a scenario, the Statute of the Nuremberg Tribunal, the ad-hoc tribunals created in the framework of the United Nations and the Rome Statute of the International Criminal Court expressis verbis declares the irrelevance of official capacity. However, there is no possibility under contemporary international law to create contractual obligations for a state which is not a contracting party to a treaty in question. Since the International Criminal Court does not have an executive body, it has to rely on the cooperation of its member states in order to execute the arrest warrants. In this context one could ask what can the International Criminal Court do if it wants to prosecute the siting head of state of a third state. The Court tried to resolve this issue when several member states refused to arrest Omar Hassan Ahmad Al Bashir due to its official capacity. In this article I give a short overview about the limits of contemporary international criminal law and I offer a possible solution as well.

Keywords: Al Bashir, International Criminal Court, Rome Statute, Article 27, Article 98, Sudan, Darfur, Head of state immunity, United Nations Security Council, Obligation to cooperate, UNSC RES 1593

\section{BEVEZETÉS}

Az Egyesült Nemzetek Szervezetének Biztonsági Tanácsa (a továbbiakban: ENSZ BT) az Alapokmány (a továbbiakban: Alapokmány) VII. fejezete alapján eljárva 1593. számú határozatával utalta a Római Statútumban (a továbbiakban: Statútum) nem részes, Szudán Dárfúr regiójában történt események kivizsgálását a Nemzetközi Büntetőbíróság (a 
továbbiakban: Bíróság) hatáskörébe. Ennek alapján letartóztatási parancsot adott ki Szudán de facto és de jure elnöke, Omar Hassan Ahmad Al Bashir ellen két rendbeli háborús bűncselekmény, öt rendbeli emberiesség elleni bűncselekmény és három rendbeli népirtás vádjával. $\mathrm{Al}$ Bashir a letartóztatási parancs ellenére több alkalommal utazott egy, a Statútumban részes állam területére. Ezek az államok a Statútum 86. cikke alapján kötelesek lettek volna ôt letartóztatni. ${ }^{2}$ A Tárgyalás Előkészítő Kollégium Malawi, Csád, Kongó, Szudán, Uganda, Djibouti, a Dél-Afrikai Köztársaság és a Jordániában tett látogatását alapul véve állapította meg az együttműködési kötelezettség megszegését, az ügyet pedig az ENSZ BT és a Szerződő Államok Közgyúlése elé utalta. ${ }^{3}$ Az Afrikai Unió kérvényezte, hogy a Bíróság függessze fel az Al Bashir ellen indított eljárást a szudáni békefolyamatok hatékony lefolytatása érdekében, azonban a Bíróság ezt elutasította. Ennek eredményeképp az Afrikai Unió felszólította tagállamait az együttmúködési kötelezettség ignorálására. ${ }^{4} \mathrm{Az}$ érintett tagállamok és az Afrikai Unió az együttmúködési kötelezettség megszegésével kapcsolatos vád ellen a 27. és a 98. cikk közötti ellentétre hivatkozott az utóbbi javára. Egy korábbi írás keretén belül részletesen elemeztem a 27. és a 98. cikk közötti kollízió gyökerét, ${ }^{5}$ így jelen cikk keretében csupán egy minimális áttekintést nyújtok a Bíróság esetjogának könnyebb értelmezése érdekében.

Míg a 27. cikk ${ }^{6}$ (1) bekezdése a funkcionális immunitás kérdéskörét tárgyalja, addig a (2) bekezdés a személyi immunitás irrelevanciáját mondja

2 “86. cikk Általános együttmúködési kötelezettség: A Részes Államok a jelen Statútum rendelkezéseinek megfelelően teljes mértékben együttmúködnek a Bírósággal a Bíróság joghatóságába tartozó bűntettek miatti nyomozás és büntetőeljárás során.”

3 Jordánia esetében visszavonta az ENSZ BT és a Közgyűlés elé utalást, míg az együttmûködési kötelezettség megszegésével kapcsolatos ítéletét fenntartotta. Forrás: https://www.icc-cpi.int/Pages/item.aspx?name=pr1452

${ }^{4}$ ASSEMBLy OF THE AFRICAN UNION, 2009.

${ }^{5}$ PESCi, 2019. 44-63.o.

6 “27. cikk A hivatalos minőség figyelmen kívül hagyása a büntetőjogi felelősség szempontjából 1. A jelen Statútum a hivatalos minőségre való tekintet nélkül egyaránt vonatkozik minden személyre. Semmilyen körülmények között sem mentesíti az adott személyt a jelen Statútum szerinti büntetőjogi felelősség alól különösen az állam- vagy kormányfői tisztséggel, kormány- vagy parlamenti tagsággal, választott képviselői vagy kormányhivatalnoki tisztséggel járó hivatalos minőség, és mint olyan, nem indokolja a büntetés mérséklését. 2. A nemzeti vagy a nemzetközi szabályok szerint a hivatalos minőséggel járó mentességek, vagy különleges eljárási szabályok nem akadályozzák a Bíróságot az adott személy fölött joghatóságának gyakorlásában.” 
ki. $^{7}$ Nyilvánvalóvá teszi, hogy a Statútum 5. cikkében meghatározott valamely bûncselekmény elkövetésének gyanúja esetén, a gyanúsított személy büntetőjogi felelősségére az általa betöltött hivatalos pozíció befolyással nem rendelkezik, ezáltal a Bíróság joghatósága főszabály szerint megállapítható. $^{8}$ Ezen rendelkezés a nemzetközi szokásjog deklaratív megnyilvánulásának tekinthető, amely nemzetközi bűncselekmények esetén kizárja a funkcionális immunitás intézményét ${ }^{9}$ és megerôsíti a személyi immunitás irrelevanciáját. ${ }^{10}$ Kijelenthető tehát, hogy a 27. cikk a büntetőjogi felelősség problémáját taglalja, míg az immunitás eljárásjogi kérdésnek tekintendő. ${ }^{11}$ Ezt az álláspontot tükrözi a nemzetközi büntető bíróságok gyakorlata, mivel statútumukat az adott bíróság természetével összhangban értelmezték. ${ }^{12} \mathrm{Az}$ immunitás irrelevanciájának indoka ezért nem az adott paragrafusban keresendő, hanem magának a bíróságnak a természetében, mely kívül áll a szorosan értelmezett államok közötti kapcsolatokon, míg az immunitás intézménye jellemzően az utóbbi kategóriában értelmezhető. ${ }^{13}$

A 27. cikk (2) bekezdése megszünteti a nemzetközi bűncselekményekkel megvádolt személyek immunitását a Bíróság eljárásának tekintetében, míg a 98. cikk (1) bekezdése ${ }^{14}$ megtiltja, hogy együttműködésre hívjon fel egy részes tagállamot amennyiben ez a kérelem a kérelmezett által harmadik ország irányába fennálló nemzetközi szokásjogi kötelezettségének megsértéséhez vezetne. ${ }^{15}$ Erre az összefüggésre - számos részes tagállam és jogtudós értelmezésében - csupán harmadik államok hivatkozhatnak, míg részes tagállamok nem bújhatnak a két rendelkezés közötti ellentét mögé

\footnotetext{
7 SUMMERS, 2006.

${ }^{8} \mathrm{KING}, 2006$.

9 Prosecutor v Tihomir BlašKić (Judgement) IT-95-14-A (18 July 1997) 140.

10 TRIFFTERER, 2008.

11 Difference Relating to ImMunity from Legal Process of a Special RAPPORTEUR OF THE COMMISSION OF HUMAN RIGHTS, 1999.

12 KitTiCHAisAREE, 2001.

13 Prosecutor v Radislav KrstiĆ (Judgement) IT-98-33-A (1 July 2003) 26.

14 “98. cikk A mentességről való lemondással és az átadáshoz való hozzájárulással kapcsolatos együttmúködés 1. A Bíróság nem terjeszthet elő olyan átadás vagy jogsegély iránti kérelmet, amely a Megkeresett Államot olyan cselekményekre kényszerítené, amelyek ellentétesek lennének nemzetközi jogi kötelezettségeivel az államok mentessége, vagy egy harmadik államhoz tartozó személy diplomáciai mentessége, illetve egy harmadik állam tulajdona tekintetében, kivéve ha a Bíróság előzetesen megszerzi a harmadik Állam együttműködését a mentességről való lemondáshoz."

15 CAssese, 2008. 990.o.
} 
amennyiben hivatalos pozíciót betöltő állampolgára egy másik állam területén tartózkodik. ${ }^{16}$

\section{A DÁRFÚRI KONFLIKTUS}

Dárfúr Szudán egyik - nyugati - régiója, amely a Közép-afrikai Köztársasággal, Líbiával, Csáddal és Dél-Szudánnal határos. Szudán etnikai összetétele rendkívül sokszínű, amely a Nílus völgyének őslakosaiból és az Arab-félszigetről bevándorolt népcsoportokból tevődik össze. Összesen 19 etnikai csoport különböztethető meg egymástól, melyek több mint 100 nyelvet és dialektust beszélnek. ${ }^{17}$ Ennek köszönhetően egy kulturálisan rendkívül széttagolt ország jött létre. Az ország több mint 40 milliós lakosságának ${ }^{18} 70 \%$-át a szudáni arabok adják. ${ }^{19}$

A teljesség igénye nélkül, a dárfúri konfliktus gyökere az arab és nem arab etnikai csoportok között kialakult ellentétre vezethető vissza, amely az ívóvízhiányból és az ennek következményeként beállt élelmezési problémákból fakadt. ${ }^{20}$ A Szudáni Felszabadító Hadsereg és az Igazság és Egyenlőség Mozgalom 2003-ban támadást indított a szudáni kormány ellen, amelyet a nem-arab lakossággal szemben alkalmazott diszkriminatív tevékenységekkel vádolt. ${ }^{21}$ Válaszként a szudáni kormány - amelynek 1993 óta regnáló államfője $\mathrm{Al} \mathrm{Bashir}^{22}$ - arab paramilitáris erőket (Janjaweed) fegyverzett fel a dárfúri felkelők visszaszorítása érdekében. A milícia a régióban élő nem arab etnikumok földjeit felégette, a populációt kiéheztette, kitelepítette és tömegmészárlásokat követett el. ${ }^{23} \mathrm{Az}$ ENSZ jelentése alapján 2003-ban a szudáni kormányerők, a Janjaweed és egyéb fegyveres milíciák között kirobbant nem nemzetközi fegyveres konfliktusban megközelítőleg 200.000 ember vesztette életét és több mint 2.000.000 személy áttelepítésére került sor Szudánon belül és kívül. ${ }^{24}$ Ugyan a kormányzat mindvégig tagadta, hogy bárminemú kapcsolatban állna a milíciával, a bizonyítékok ennek ellenkezőjére utaltak.

\footnotetext{
16 WirTH, 2001. 429.o.

17 MWANIKi, 2019.

18 United NATIONS POPULATION Division

19 THE WORLD FACTBOOK, AFrICA: SUDAN

20 WACHMAN, 2007.

${ }^{21}$ Q\&A: SUDAN'S DARFUR CONFLICT

22 MOORCRAFT, 2016.

${ }^{23}$ DE WAAL, 2004.

24 THE UNITED NATIONS AND DARFUR
} 
A Nemzetközi Büntetőbíróság joghatósága az államfői immunitás tükrében - Különös tekintettel az Al Bashir esetre

Az ENSZ BT 2004-ben az 1564. számú határozatával felkérte a Főtitkárt a Darfúri Helyzettel Foglalkozó Nemzetközi Vizsgáló Bizottság létrehozására, amelynek fő feladata volt annak a vizsgálata, hogy Dárfúrban történt e nemzetközi humanitárius jogot sértő tevékenység, népírtás, továbbá, hogy feltárja a lehetséges elkövetők és felelősök személyét. ${ }^{25} \mathrm{~A}$ Vizsgálóbizottság megállapította, hogy a szudáni kormány és a Janjaweed között hierarchikus irányítási viszony jött létre, amely megfelel a Tadić ügyben megállapított feltételeknek, nevezetesen: irányítás és ellenőrzés. ${ }^{26}$ Továbbá arra a következtetésre jutott, hogy ,ezeknek a kegyetlenségeknek a lehetséges felelősei egyéni elkövetők, beleértve a szudáni kormánytisztviselőket, a milíciák tagjait, a lázadó csoportok tagjait, valamint egyénileg fellépő külföldi katonatiszteket."27 A jelentés alapján az ENSZ BT 2005. március 31-én az 1593. számú határozatával az Alapokmány VII. fejezete alapján eljárva, a Statútum 13. cikk (b) ${ }^{28}$ pontjával összhangban a Bíróság Főügyésze elé utalta a dárfúri konfliktus kivizsgálását 2002. július 1ig visszamenőleg. A vizsgálat effektív lebonyolítása érdekében felhívta Szudánt és az érintett államokat a Bírósággal való együttmúködésre:

„... úgy batároz, hogy Szudán és a konfliktusban érintett valamennyi állam köteles a Nemzetközi Büntetóbirósággal és az Ügyészséggel együttmüködni és minden szü̈kéges segitséget megadni jelen határozatnak megfelelöen. Amig elismeri, hogy a Római Statútumban nem részes államoknak a Statútumból származó kötelezettségüle nincs, addig felkér valamennyi államot és az érintett nemzetközi szervezeteket az. együttmüködésre."29

Az ENSZ BT határozata alapján a Bíróság 2009. március 4-én elfogató parancsot bocsátott ki Al Bashir ellen ${ }^{30}$ két rendbeli háborús bűncselekmény, öt rendbeli emberiség elleni bűncselekmény és három

${ }^{25}$ UNSC RESOLUTION 1564 (18 September 2004) S/RES/1564

26 Prosecutor V. Du [Ko TADI] (Judgment) IT-91-1-A (15 July 1999)

27 REPORT OF THE INTERNATIONAL COMMISSION OF INQUIRY ON DARFUR TO THE UNITED NATIONS SECRETARY-GENERAL (25 January 2005) 123.

28 “13. cikk A joghatóság gyakorlása: A Bíróság joghatóságát egy, az 5. cikkben meghatározott bűntett tekintetében a jelen Statútum rendelkezései szerint akkor gyakorolhatja, ha: (b) a Biztonsági Tanács az Egyesült Nemzetek Alapokmánya VII. Fejezetének megfelelően eljárva a föügyész elé utalja azt az esetet, amellyel kapcsolatban feltehető, hogy egy vagy több ilyen bűntettet elkövettek."

${ }^{29}$ UNSC RESOLUTION 1593 (31 March 2005) S/RES/1593, 2.

30 Prosecutor V. Al Bashir (Warrant of Arrest) ICC-02/05-01/09-3 (4 March 2009) 
rendbeli népirtás vádjával. ${ }^{31}$ 2010. július 21-én a Bíróság felkérte az összes részes tagállamot $\mathrm{Al}$ Bashir letartóztatására és a Bíróságnak történő átadására. ${ }^{32}$ A letartóztatási parancs ellenére számos részes tagállam területén vendégeskedett az elmúlt kilenc évben, azonban letartóztatására a mai napig nem került sor. A Bíróság nyolc ország esetében állapította meg az együttmúködési kötelezettség megsértését és próbálta meg áthidalni a Statútum 27. cikk (2) bekezdése és a 98. cikk (1) bekezdése között uralkodó feszültséget. A Bíróság - a Statútummal összhangban - az érintett állam és a Szudán között fennálló viszonyára való tekintettel kísérelte meg az $\mathrm{Al}$ Bashir-t megillető immunitás felfüggesztését. Jelen írás keretében a Bíróság érvelésének fejlődését és a döntések közös pontjait vizsgálom.

\section{A NEMZETKÖZI BÜNTETŐBÍRÓSÁG ESETJOGA}

\subsection{Nemzetközi büntetőbíróságok előtt az immunitás irreleváns}

A Bíróság Tárgyalás Előkészítő Kollégiuma Malawi ${ }^{33}$ és Csád ${ }^{34}$ esetében döntését a korábbi nemzetközi büntető fórumok statútumára alapozta, amelyek rögzítették, hogy a hivatalos státusz nem mentesít a büntetőjogi felelősség alól. A Bíróság ugyan felismerte a 27. és a 98. cikkek között uralkodó feszültséget, ugyanakkor annak érdemi feloldása nélkül megállapította, hogy egyik ország sem jogosult a 98. cikk (1) bekezdésének rendelkezésére hivatkozni az együttműködési kötelezettségek tekintetében. ${ }^{35}$ Döntését négy fó érvre alapozta: (1) az I. világháború óta a személyi immunitás irreleváns a nemzetközi bíróságok előtt, (2) a hivatalban lévő államfők ellen folytatott nemzetközi eljárások számának a növekedése, (3)

\footnotetext{
31 AlLEged Crimes (NON-EXHAustive LiST)

32 Prosecutor V. Al Bashir (Supplementary Request to All States Parties to the Rome Statute for the Arrest and Surrender of Omar Hassan Ahmad Al Bashir) ICC-02/0501/09-96 (21 July 2010)

33 Prosecutor V. Al Bashir (Corrigendum to the Decision Pursuant to Article 87(7) of the Rome Statute on the Failure by the Republic of Malawi to Comply with Cooperation Requests Issued by the Court with Respect to the Arrest and Surrender of Omar Hassan Ahmad Al Bashir) ICC-02/0501/09-139 (13 December 2011)

34 Prosecutor V. Al Bashir (Decision pursuant to Article 87(7) of the Rome Statute on the Refusal of the Republic of Chad to comply with the cooperation requests issued by the Court with respect to the arrest and surrender of Omar Hassan Ahmad Al Bashir) ICC02/05-01/09-140 (13 December 2011)

35 Uo. 37.
} 
120 állam ratifikálta a Statútumot, amelyek ezáltal elfogadták a hivatalos státusz irrelevanciáját, (4) ellentmondásos és elképzelhetetlen az a tény, hogy hatáskört delegálnak egy büntető fórum számára nemzetközi bűncselekmények elkövetőinek vizsgálat alá vonása érdekében, míg ezzel szemben oly módon értelmezik annak Statútumát, hogy múködését lehetetlenné teszik. ${ }^{36}$ Mindezek alapján megállapította, hogy a nemzetközi szokásjogban ismertek az államfói immunitás alóli kivételek. ${ }^{37}$

Ugyanakkor a Bíróság érvelése számos ponton problémába ütközik. Egyrészt, a korábbi nemzetközi büntető fórumok rendelkezései az immunitás tekintetében a büntetőjogi felelősséget taglalják, amely nem összekeverendő a joghatóság kérdésével. Másrészt, ezen bíróságok statútumai kizárólag az érintett államokra - a vádlott országára - nézve állapítottak meg rendelkezéseket. ${ }^{38}$ Hasonlóképpen, a hágai Nemzetközi Bíróság a letartóztatási parancs ügyben csupán annyit állapított meg, hogy a külügyminiszterek alanyai lehetnek büntető eljárásoknak bizonyos nemzetközi büntetőbíróságok előtt, amelyek joghatósággal rendelkeznek az adott ügy tekintetében. ${ }^{39}$ Nemkülönben a Volt Jugoszláv Területeken Elkövetett Bűncselekmények Nemzetközi Törvényszéke a Blaškić ügyben arra az álláspontra jutott, hogy a mentelmi jog nem szűnik meg csupán amiatt, hogy az ügyben eljáró bíróság nemzetközi. ${ }^{40}$ Ezt az álláspontot erôsíti meg Shahabudden Bíró különvéleménye is a Krstić ügyben. ${ }^{41}$

Még ha el is fogadjuk, hogy a Bíróságnak igaza van abban, hogy egy nemzetközi büntetőbíróság előtt a hivatalos státuszból adódó immunitás irreleváns, látnunk kell azt, hogy ezzel egy időben elmulasztotta megfogalmazni a horizontális relációra vonatkozó iránymutatást, amely lehetővé tenné egy részes állam számára a kérelmezettôl eltérô állam hivatalban lévő államfőjének letartóztatását. ${ }^{42}$ Másként, a Bíróság nem tett különbséget a részes és nem részes államok között a 98. cikk értelmezése során, ${ }^{43}$ amelynek értelme ily módon kiüresedne. A részes és nem részes

\footnotetext{
36 Uo. 38-42.

37 UO. 43.

38 AKANDE, 2003.

39 CASE CONCERning THE ARrest WarRant of 11 ApriL 2000 (Democratic Republic of Congo v Belgium) ICJ Judgment of 14 February 2002. 61.

${ }^{40}$ Forrás: http://www.icty.org/en/sid/7485

${ }^{41}$ Dissenting OpINION OF JUdGE SHAHABUdDEN

${ }^{42}$ Chernor - BANTEKas, 2017.

${ }^{43}$ NTOMbizozUKO, 2017.
} 
államok közötti különbségtételt számos ország nemzeti jogalkotása beemelte jogrendjébe. ${ }^{44}$

\subsection{Az ENSZ BT határozata, mint egy implicit lemondás}

A Bíróság felismerve a korábbi döntései során hozott érvelésének hiányos voltát, Kongóval, Dijiboutival, Ugandával és Dél-Afrikával szemben lefolytatott eljárása során ítéletének jogalapját gyökeresen megváltoztatta. ${ }^{45}$ Amennyiben elfogadjuk, hogy a személyi immunitás alóli kivételek lehetősége a megfelelő mennyiségű és minőségű nem tagállami gyakorlat miatt nem állapítható meg, úgy az ENSZ BT kötelező erejű határozatával, eseti jelleggel állapíthatja meg a mentelmi jog hiányának tényét a Bíróság joghatóságának megalapozása érdekében. ${ }^{46}$ Ennek megfelelően a Tárgyalás Előkészítő Kollégium érdemében vizsgálta a 27. cikk (2) bekezdés és a 98. cikk (1) bekezdés között uralkodó feszültséget és arra a megállapításra jutott, hogy Szudán együttmúködési kötelezettsége az ENSZ BT által kibocsátott 1593. számú határozatából ered.

A Tárgyalás Előkészítő Kollégium ugyan elismerte az államfői immunitás szokásjogát a Statútum ratifikálására való tekintet nélkül azonban megerősítette, hogy eljárása során a 27 . cikk értelmezése alapján mentelmi jogosultság nem illeti meg az eljárás alá vont személyt. Ezzel egyidôben rámutatott arra, hogy a Statútum a nemzetközi közjog normarendszerének megfelelően kizárólag azon államokra nézve állapíthat meg kötelező rendelkezéseket, amelyek azt ratifikáltak így a 98. cikk (1) bekezdésével

\footnotetext{
44 AKANDE, 2018.

45 Prosecutor V. Al Bashir (Decision on the Cooperation of the Democratic Republic of the Congo Regarding Omar Al Bashir's Arrest and Surrender to the Court) ICC-02/0501/09-195 (9 April 2014); ProseCUTOR V. Al BASHIR (Decision following the Prosecutor's request for an order further clarifying the Republic of South Africa is Under the obligation to immediately arrest and surrender Omar Al Bashir) ICC-02/05-01/09242 (13 June 2015); PROSECUTOR V. Al BASHIR (Decision on the non-compliance by the Republic of Djibouti with the request to arrest and surrender Omar Al Bashir to the Court and referring the matter to the United Nations Security Council and the Assembly of the State Parties to the Rome Statute) ICC-02/05-01/09-266 (11 July 2016); PrOSECUTOR V. AL BASHIR (Decision on the non-compliance by the Republic of Uganda with the request to arrest and surrender Omar Al Bashir to the Court and referring the matter to the United Nations Security Council and the Assembly of State Parties to the Rome Statute) ICC-02/05-01/09-267 (11 July 2016)

46 i.m. TRIFFTERER 2139.
} 
összhangban köteles a "harmadik állam” együttműködését biztosítani. ${ }^{47}$ Ugyanakkor kifejtette, hogy ezen értelmezés az Alapokmány VII. fejezete alapján meghozott kötelező erejű határozata által derogálható, amely a nem részes tagállamok együttműködésére vonatkozó kötelezettséget állapít meg. ${ }^{48}$ Ennek megfelelően egy részes tagállamnak a Bíróság által kibocsátott letartóztatási parancsának a végrehajtása nem tekinthető a nemzetközi jogból származó kötelezettségeivel ellentétes cselekedetnek. Megállapítását melyet a kongói precedenst követő ítéletek érvelése konzekvensen követ - a következőkre alapozta:

(i.) Az ENSZ BT által kibocsátott 1593. számú határozata, amely kötelezi Szudánt a Bírósággal és az Ügyészséggel való együttmúködésre, megszüntette a letartóztatás foganatosításának minden akadályát és felfüggesztette $\mathrm{Al}$ Bashir mentelmi jogát, amely megfelel a 98. cikk (1) bekezdése által támasztott együttmúködési nyilatkozatra vonatkozó kötelezettségnek.

(ii.) Az ENSZ BT által kibocsátott határozata implicit módon felfüggesztette az államfői státuszához kapcsolódó immunitását, melynek következményeként horizontális viszonylatban sem állapítható meg letartóztatást kizáró körülmény.

(iii.) Az ENSZ BT az Alapokmány VII. fejezete alapján kibocsátott határozata felülírja az Afrikai Unió Alapokmányából eredő kötelezettségeket. ${ }^{49}$

A Tárgyalás Előkészítő Kollégium döntése alapján Szudánt a Statútumból eredő kötelezettségek terhelik, melyből kifolyólag a 27. cikk nyomán Al Bashir hivatalos státusza irrelevánsa válik, s ezáltal a 98. cikk (1) bekezdése nem alkalmazható. Ugyanakkor a Bíróság érvelése rendkívül problémás, mivel élesen szembe megy a nemzetközi közjog alapvetői normáival. A Szerződések Jogáról szóló 1969. évi Bécsi Egyezmény 34. cikkében $^{50}$ kifejtett, a nemzetközi szerződések fő mozgatórugójának ${ }^{51}$

\footnotetext{
${ }^{47}$ I.M. CONGO, 2014. 27.

48 I.M. CONGO, 2014. 10.

${ }^{49}$ I.M. CONGO, 2014. 24-31.

50 “34. Cikk Harmadik államra vonatkozó általános szabály: A szerződés harmadik állam számára - annak beleegyezése nélkül - sem kötelezettségeket, sem jogokat nem hoz létre.”
} 
tekinthető pacta tertiis nec nocent nec prosunt elvének értelmében egy nemzetközi szerződés nem hozhat létre kötelezettségeket egy harmadik ország terhére annak beleegyezése nélkül. Fontos megjegyeznünk, hogy ugyan Szudán az Alapokmány részese, amely bizonyos hatásköröket delegál az ENSZ BT javára, azonban ezek a hatáskörök meghatározott korlátokkal rendelkeznek.

Egyrészt, az ENSZ BT által kibocsátott határozat a Statútum 13. cikk (b) bekezdésének megfelelően csupán a Bíróság joghatósága gyakorlásának egyik feltétele, nem pedig a hatáskörének a forrása. ${ }^{52}$ A 13 . cikkben alkalmazott valamely joghatósági feltétel teljesülésének nincs kihatása a 27. cikk alkalmazására. Ezen rendelkezés nem kívánja meg a Bíróságtól, hogy saját eljárási szabályaitól eltérő normákat alkalmazzon. Ennek megfelelően, a 19. cikk (1) bekezdésével összhangban a Bíróság első számú kötelezettsége, hogy meggyőződjön arról, hogy rendelkezik-e joghatósággal és ez által az adott ügy befogadható-e, még abban az esetben is amennyiben az ENSZ BT utalta a Bíróság elé az ügyet. ${ }^{53}$ A Bíróságnak nincs kötelezettsége arra vonatkozólag, hogy egy ügyet kivizsgáljon, még abban az esetben sem, ha az az ENSZ BT-tôl származik. Valamennyi nemzetközi szervezet - mint amilyen a Bíróság is - a részes tagállamok által ráruházott jogosultságokhoz van kötve. ${ }^{54}$ Ennek megfelelően, az ENSZ-nek nincs lehetősége kiegészítő hatáskörök delegálására. ${ }^{55}$ Következésképpen, amennyiben Szudán együttmúködési kötelezettségének nem tesz eleget úgy kizárólag az Alapokmánnyal ellentétes magatartást tanúsít, amelynek nincs kihatása a horizontális és vertikális kapcsolatokra. ${ }^{56}$

Másrészt, a mentelmi jog felfüggesztésének követelménye az Alapokmány 2. cikkében ${ }^{57}$ expressis verbis rögzített, az államok szuverén

\footnotetext{
51 SCHEFFER, 1999.

52 GAETA, 2014.

53 I.M. NTOMBIZOZUKO 556.

54 SCHERMERS, 2011.

55 CASSESe, 2002.

56 I.M. AKANDE, 2018.

57 "2. Cikek: Az 1. cikekben felsorolt célok elérése érdekében a Szervezut és tagjai a követkerô" elveknek megfelelóen járnak el: 1. A Szervezet valamennyi tag szuverén egyenlöségének elvén alapszik. 7. A jelen Alapokmány egyetlen rendelkęése sem jogositja fel az Egyesült Nemzeteket arra, hogy olyan ügyekbe avatkozzanak, amelyek lényegileg valamely Állam belsö joghatóságának körébe tartoznak és nem kötelezi a tagokat arra sem, hogy az ilyen ügyeket a jelen Alapokmánynak megfelelö rendezési eljárás alá bocsássák; ez az elv azonban a VII. fejezetben tárgyalt kényszueritö intézkedések alkalmazását semmiben sem érinti."
} 
egyenlőségén és a par in parem non habet imperium elvén alapszik. ${ }^{58}$ Kizárólag az érintett állam jogosult az immunitás felfüggesztésére mivel az hozzá és nem az egyénhez kapcsolódik. ${ }^{59}$ A felfüggesztő vagy lemondó nyilatkozatnak minden esetben határozottnak kell lennie. ${ }^{60}$ Ennek megfelelően a 98. cikk (1) bekezdése a Szerződések Jogáról szóló 1969. évi Bécsi Egyezmény rendelkezéseivel összhangban alkalmazást nyer. Az egyedüli kivételt az ENSZ BT által kibocsátott explicit határozata kepézheti. ${ }^{61}$ A hágai Nemzetközi Bíróság döntése nyomán az ENSZ BT határozatait az eset összes körülményeit mérlegelve kell értelmezni. ${ }^{62}$ Amennyiben az 1593. számú határozat tartalmát vizsgáljuk nyilvánvalóvá válik, hogy csupán Szudán és az érintett ENSZ tagállamok együttmúködését írja elő, ugyanakkor nem találunk egyetlen olyan rendelkezést sem, amely $\mathrm{Al}$ Bashir immunitását érintené. Mivel - ahogy azt a korábbi tanulmányban részletesen kifejtettem - a mentelmi jog az államok szuverén egyenlőségéből fakadó jogintézmény, így bárminemú utalásnak határozott kifejezésekben kell testet öltenie. ${ }^{63}$ Ennek megfelelően megállapítható, hogy az ENSZ BT határozata az immunitás kérdés körét nem érinti.

\subsection{Szudán, mint „kvázi” részes tagállam}

A Bíróság Tárgyalás Előkészítő Kollégiuma 2017 folyamán DélAfrikát $^{64}$ és Jordániát ${ }^{65}$ elmarasztalta a Bírósággal való együttműködés elmulasztása és Al Bashir letartóztatásának elmaradásából kifolyólag. A Tárgyalás Előkészítő Kollégium érvelése alapján - amely meglátásom szerint eddig a legmeggyőzőbb - Szudán a dárfúri helyzetre korlátozva, a

58 THIRD REPORT ON IMMUNITY OF STATE OFFICIALS FROM FOREIGN CRIMINAL JURISDICTION (24 May 2011) A/CN.4./646, 32. P (a továbbiakban: ILC 3.)

${ }^{59}$ ILC 3, 33.

${ }^{60}$ ILC 3, 55.

61 i.m. KING 278.

62 Legal Consequences for States of The Continued Presence of South Africa IN NAMIBIA (Advisory Opinion) ICJ 21 June 1971.

${ }^{63}$ I.M. PESCI, 2019. 56.

${ }^{64}$ Prosecutor V. Al BAshir (Decision under article 87(7) of the Rome Statute on the non-compliance by South Africa with the request by the Court for the arrest and surrender of Omar Al-Bashir) ICC-02/05-01/09-302 (6 July 2017) (6 July 2017)

65 Prosecutor v. Al Bashir (Decision under article $87(7)$ of the Rome Statute on the non-compliance by Jordan with the request by the Court for the arrest and surrender or Omar Al-Bashir) ICC-02/0501/09-309 (11 December 2017) 
Statútumban részes tagállamokhoz hasonló jogosultságokkal és kötelezettségekkel rendelkezik. ${ }^{66}$ Ítéletét a következő érvekre alapozta:

A Bíróság joghatóságát az ENSZ BT 1593. számú határozata alapozta meg, melynek következményeként a Statútum és a hozzá kapcsolódó dokumentumok nyernek alkalmazást. Az Alapokmány VII. fejezete alapján az ENSZ BT jogosult olyan szerződéses kötelezettségek megállapítására, amelynek az érintett állam nem részese. Ennek következményeként a 27. cikk alkalmazást nyer, melynek értelmében mind Szudán, mind az érintett tagállamok kötelesek Al Bashir letartóztatására és a Bíróságnak történő átadására.

(ii) Az ENSZ BT határozata nem tartalmaz rendelkezéseket a mentelmi jog felfüggesztésének vonatkozásában azonban az nem is szükséges, mivel az előzőek alapján nincs immunitás ami felfüggeszthető.

Látható, hogy a korábbi esetjogától eltérően a Bíróság egy merőben más érvelési technikát alkalmaz, ami meglátásom szerint rendkívül meggyőző, azonban még mindig nem teljes. A Bíróság ítélete alapján Szudán egy kvázi részes tagállammá vált, melyből kifolyólag a 98. cikk (1) bekezdésére történő hivatkozás kizárt. Annak ellenére, hogy Szudán nem részese a Statútumnak az Alapokmányból származó kötelezettségeinek megfelelően köteles elfogadni az ENSZ BT határozatát ezáltal alávetni magát a Bíróság joghatóságának. Ennek megfelelően egy, a Statútumban részes tagállam Al Bashir letartóztatásával a nemzetközi jogi kötelezettségeivel összhangban járna el. A Bíróság érvelése azonban két pontban még mindig aggályos. Egyrészt az együttmúködési kötelezettség elő́rása semmilyen esetben sem jelentheti a mentelmi jog automatikus felfüggesztését. Szudán az ítélet elleni fellebbezésében kiemelte, hogy az ENSZ BT határozata nem határozta meg az együttmúködési kötelezettség terjedelmét, amely a Statútum 6. cikkével összhangban olvasva nem értelmezhetô oly módon, amely ilyen jellegű kötelezettséget konstruálna. ${ }^{67}$ Másrészt, látnunk kell azt is, hogy a Statútum meghatározott jogosultságokat hoz létre a részes tagállamok számára, mint például a Szerződő Államok Közgyưlésén történő részvétel joga. Ugyanakkor mindezidáig egyetlen javaslat sem érkezett egy ilyen jellegư megkeresés tekintetében.

${ }^{66}$ I.M. SOUTH AFRICA, 2017; I.M. JORDAN, 2017.

67 Prosecutor V. AL BAsHir (The Hashemite Kingdom of Jordan's appeal against the "Decision under article 87(7) of the Rome Statute on the non-compliance by Jordan with the request by the Court for the arrest and surrender [of] Omar Al-Bashir") ICC- /0501/09-326 (12 March 2018) 79-80. 
Ennek megfelelően a Bíróság illetve a jogirodalom adós maradt a Statútum „diszkriminatív” alkalmazásának a magyarázatával. ${ }^{68}$ Továbbá, ahogy Perrin de Brichamabu bíró különvéleményében kiemelte, a Statútumban vannak olyan rendelkezések, melyek kifejezetten a nem részes tagállamok tekintetében nyernek alkalmazást. Nézete alapján az a tény, hogy Szudán „kvázi” szerződéses államként kerül definiálásra nem érinti a 98. cikk (1) bekezdésének az alkalmazását, mivel az teljes mértékben kiüresítené annak tárgyát és célját. ${ }^{69}$

\section{KONKLÚZIÓ}

A kérdés továbbra is az, hogy vajon milyen megoldás mentén lehetséges a két rendelkezés közötti feszültség feloldása. Meglátásom szerint az ENSZ BT-nek egy erőteljesebb szerepet kell magára vállalnia. Ahogy az Alapokmány VII. fejezete alapján eljárva legitimálhatja a fegyveres erő alkalmazását, mely a szuverenitásba történő beavatkozás egyik legdrasztikusabb megoldása, ${ }^{70}$ úgy analóg módon az államföi immunitás is felfüggeszthető, amennyiben azt explicit módon és előzetesen rögzíti. Azonban a BT állandó tagjaira való tekintettel, melyek közül három, az Amerikai Egyesült Államok, Kína és Oroszország nem ratifikálta a Statútumot és valószínűleg nem is áll szándékában, érdemi változás a közel jövőben nem várható. 2019. április 11-én ugyanakkor érdekes fordulat következett be mivel a szudáni hadsereg megdöntötte Al Bashir hatalmát majd megerősítette a Bírósággal való együttmúködésre való hajlamát egyúttal ígéretet téve a háborús búncselekményekkel vádolt személyek, köztük az ex államfó átadására. ${ }^{71}$ Mindazonáltal érdemi előrelépés a mai napig nem történt.

A Bíróság létrejötte óta eltelt több mint két évtized után elmondható, hogy egy rendkívül produktív idôszak áll mögötte, azonban aggályos, ahogyan az Al Bashir ügyet kezelte. Egyrészt az Afrikai Unió és annak tagállamaitól éles kritikák sokaságát kapta továbbá egy tömeges kilépési folyamatot indított be az Afrikai államok részéről, amely szerencsére azóta részben megfordult. Mindezeken felül, az Amerikai Egyesült Államok a 98.

\footnotetext{
68 VENTURA, 2015.

69 Prosecutor V. Al Bashir (Minority Opinion of Judge Marc Perrin De Brichambaut) ICC-02/05-01/09-302-Anx (6 July 2017) 25.

${ }^{70}$ KOVÁCS, 2006.

71 SUDAN'S OMAR AL-BASHIR A STEP CLOSER TO FACING WAR CRIMES CHARGES, 2020.
} 
cikken alapuló bilaterális egyezmények sokaságának megkötését kezdeményezte, amely tovább gyengíti a Bíróság joghatóságát. Tovább nehezítheti a Bíróság múködését, hogy Donald Trump, az USA elnöke 2020. június 11-én kiadott rendeletében ${ }^{72}$ felhatalmazást adott arra, hogy szankciókat alkalmazzanak a Bíróság azon munkatársaival szemben, akik részt vesznek az amerikai csapatok Afganisztánban elkövetett háborús bűncselekményeinek kivizsgálásában. A célzott szankcióknál jóval nagyobb jelentőségű, hogy az elnöki rendelet „második körös” szankciókra is felhatalmazást ad, amelyek alapján mindazon természetes és jogi személyek is szankcionálhatók, amelyek a vizsgálatokat bármilyen módon segítik vagy a szankció alá helyezett személyeknek nyújtanak bármilyen támogatást. Donald Trump július 11-i elnöki rendelete alapján megnyílt felhatalmazással élve Mike Pompeo szeptember 2-án közölte, hogy az amerikai Pénzügyminisztérium a Bíróság két vezetô tisztségviselőjét, Fatou Bensouda Főügyészt és Pakisho Mochochokót, a Bíróság joghatósági ügyekkel foglalkozó részlegvezetójét helyezte szankciók alá. ${ }^{73}$ Mindezek alapján látható, hogy politikai akarat hiányában a nemzetközi bűncselekmények lehetséges elkövetőinek felelősségre vonásához gyakran nem elegendő a jogszabályi keretek megléte.

\section{FELHASZNÁLT IRODALOM}

A SZERZŐDÉSEK JOGÁRÓL SZÓLÓ 1969. ÉVI BÉCSI EGYEZMÉNY

A NEMZETKÖZI BÜNTETŐBÍRÓSÁG RÓMAI STATÚTUMA

AKANDE, DAPO (2018), The Immunity of Heads of States of Nonparties in the Early Years of the ICC, American Journal of International Law, Vol.112. DOI azonosító: https://doi.org/10.1017/aju.2018.56

AKANDE, DAPO (2003), The Jurisdiction of the International Criminal Court over Nationals of Non-Parties: Legal Basis and Limits, Journal of International Criminal Justice, Vol.1. DOI azonosító: https://doi.org/10.1093/jicj/1.3.618

\footnotetext{
72 Executive Order on Blocking Property Of Certain Persons Associated With The International Criminal Court. Forrás: https://www.whitehouse.gov/presidentialactions/executive-order-blocking-property-certain-persons-associated-internationalcriminal-court/

${ }^{73}$ Blocking Property of Certain Persons Associated with the International Criminal Court Designations. Forrás: https://home.treasury.gov/policy-issues/financial-sanctions/recentactions/20200902
} 
AL BASHIR CASE: ICC Appeals Chamber confirms Jordan's noncooperation but reverses the decision referring it to the ASP and UNSC. Elérhető: https://www.icc-cpi.int/Pages/item.aspx?name $=$ pr1452

AlLEGED CRIMES (non-exhaustive list). Elérhető: https://www.icccpi.int/darfur/albashir/pages/alleged-crimes.aspx

ALLGEMEINES LANDRECHT FÜR DIE PREUSSISCHEN STAATEN, 1794. 22. és 77. szakasz.

ASSEMBLy OF THE AFRICAN UNION Thirteenth Ordinary Session (1-3 July 2009). Elérhető: https://au.int/sites/default/files/decisions/9560assembly en 13 july 2009 auc thirteenth ordinary session decisions declarations message congratulations motion 0.pdf

Blocking Property of CERTAIN PERSONS Associated with THE INTERNATIONAL CRIMINAL COURT DESIGNATIONS. Elérhető: https://home.treasury.gov/policy-issues/financial-sanctions/recentactions $/ 20200902$

Case Concerning the Arrest Warrant of 11 April 2000 (Democratic Republic of Congo v Belgium) ICJ Judgment of 14 February 2002.

Cassese, Antonio (2002), When May Senior State Officials Be Tried for International Crimes? Some Comments on the Congo v Belgium Case, European Journal of International Law, Vol.13. DOI azonosító: https://doi.org/10.1093/ejil/13.4.853

CASSESE, ANTONIO (2008), International Criminal Law, Oxford University Press. DOI azonosító: $\quad$ https://doi.org/10.1111/j.1748121X.2008.00116 4.x

Chernor, Charles; Bantekas, Ilias (2017), The International Criminal Court and Africa, Oxford University Press, DOI azonosító: 10.1093/oso/9780198810568.001.0001

DR WAAL, ALEX (2004): Darfur's deep grievances defy all hopes for an easy solution, The Guardian.

Elérhető: https://www.theguardian.com/society/2004/jul/25/internationalaidand development.voluntarysector

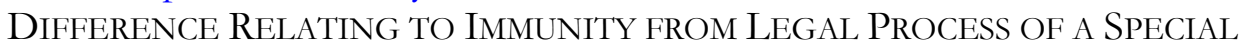
Rapporteur of the Commission of Human Rights, ICJ Advisory Opinion of 29 April 1999.

Dissenting OpINION OF Judge ShaHABudDen. Elérhető: http://www.icty.org/x/cases/krstic/acdec/en/030701do.html

Executive Order on Blocking Property OF CERTAin PERSONS Associated With The International Criminal CourT. Elérhető: 
https://www.whitehouse.gov/presidential-actions/executive-orderblocking-property-certain-persons-associated-international-criminalcourt/

Gaeta, Paola, Guest Post (2014): The ICC Changes Its Mind on the Immunity from Arrest of President Al Bashir, But It Is Wrong Again. Elérhető: http://opiniojuris.org/2014/04/23/guest-post-icc-changesmind-immunity-arrest-president-al-bashir-wrong/

KING, Hugh (2006), Immunities and Bilateral Immunity Agreements: Issues Arising From Articles 27 and 98 of the Rome Statute, New Zealand Journal of Public and International Law, Vol.4.

KitTiCHAisAREE, KRIANGSAK (2001), International Criminal Law, Oxford University Press

KOVÁCs PÉTER (2006), The question of use of force in the UN coordinates - before changes?, Miskolc Journal of International Law, Vol.3, DOI azonosító: 10.1556/АЈ и г.47.2007.1.3

Legal Consequences for States of The Continued Presence of SOUTH AFriCA IN NAmiBIA (Advisory Opinion) ICJ 21 June 1971.

MoOrCraft, PAul (2016), Omar Al-Bashir and Africa's Longest War, Pen and Sword. DOI azonosító: https://doi.org/10.1093/afraf/adw060

MWANIKI, ANDREW (2019), Ethnic Groups of Sudan. Elérhető: https://www.worldatlas.com/articles/the-ethnic-groups-in-sudan.html Ntombizozuko, Dyani-Mhango (2017), South Africa's Dilemma: Immunity Laws, International Obligations, and the Visit by Sudan's President Omar Al Bashir, Washington International Law Journal, Vol.26.

Pesci MARCo (2019), A Római Statútum Rendelkezései Harmadik Államok Vonatkozásában, Külügyi Múhely, Vol.1. DOI azonosító: https://doi.org/10.36817/KM.2019.1.3

Prosecutor V. Al BASHIR (Corrigendum to the Decision Pursuant to Article 87(7) of the Rome Statute on the Failure by the Republic of Malawi to Comply with Cooperation Requests Issued by the Court with Respect to the Arrest and Surrender of Omar Hassan Ahmad Al Bashir) ICC-02/0501/09-139 (13 December 2011)

Prosecutor V. AL BASHIR (Decision on the Cooperation of the Democratic Republic of the Congo Regarding Omar Al Bashir's Arrest and Surrender to the Court) ICC-02/05-01/09-195 (9 April 2014)

Prosecutor V. Al BASHIR (Decision following the Prosecutor's request for an order further clarifying the Republic of South Africa is Under the 
obligation to immediately arrest and surrender Omar Al Bashir) ICC02/05-01/09242 (13 June 2015)

Prosecutor V. Al BASHIR (Decision on the non-compliance by the

Republic of Djibouti with the request to arrest and surrender Omar Al Bashir to the Court and referring the matter to the United Nations Security Council and the Assembly of the State Parties to the Rome Statute) ICC-02/05-01/09-266 (11 July 2016)

Prosecutor v. Al Bashir (Decision on the non-compliance by the Republic of Uganda with the request to arrest and surrender Omar AlBashir to the Court and referring the matter to the United Nations Security Council and the Assembly of State Parties to the Rome Statute) ICC-02/0501/09-267 (11 July 2016)

ProseCutor V. Al Bashir (Decision pursuant to Article 87(7) of the Rome Statute on the Refusal of the Republic of Chad to comply with the cooperation requests issued by the Court with respect to the arrest and surrender of Omar Hassan Ahmad Al Bashir) ICC-02/05-01/09-140 (13 December 2011)

Prosecutor V. Al Bashir (Decision under article 87(7) of the Rome Statute on the non-compliance by South Africa with the request by the Court for the arrest and surrender of Omar Al-Bashir) ICC-02/0501/09-302 (6 July 2017) (6 July 2017)

Prosecutor V. Al BASHIR (Decision under article 87(7) of the Rome Statute on the non-compliance by Jordan with the request by the Court for the arrest and surrender or Omar Al-Bashir) ICC-02/0501/09-309 (11 December 2017)

Prosecutor v. Al BASHIR (MINORITY OPINION OF JUDGE MARC PERRIN DE BRICHAMBAUT) ICC-02/05-01/09-302-Anx (6 July 2017)

Prosecutor V. Al Bashir (Supplementary Request to All States Parties to the Rome Statute for the Arrest and Surrender of Omar Hassan Ahmad Al Bashir) ICC-02/05-01/09-96 (21 July 2010)

Prosecutor V. Al Bashir (The Hashemite Kingdom of Jordan's appeal against the "Decision under article 87(7) of the Rome Statute on the non-compliance by Jordan with the request by the Court for the arrest and surrender [of] Omar Al-Bashir") ICC- /05-01/09-326 (12 March 2018)

Prosecutor V. Al BASHIR (Warrant of Arrest) ICC-02/05-01/09-3 (4 March 2009) 
Prosecutor v. Du [Ko Tadi] (Judgment) IT-91-1-A (15 July 1999)

Prosecutor V. RAdisLAV KrSTIĆ (Judgement) IT-98-33-A (1 July 2003)

PROSECUTOR V. TIHOMIR BLAŠKIĆ (Judgement) IT-95-14-A (18 July 1997)
Q\&A:
SUDAN'S
DARFUR
CONFLICT.
Elérhető:

http://news.bbc.co.uk/2/hi/africa/3496731.stm

REPORT OF THE INTERNATIONAL COMMISSION OF INQUIRY ON DARFUR TO THE UNITED NATIONS SECRETARY-GENERAL (25 January 2005)

SCHEFFER, DAVID J. (1999), The United States and the International

Criminal Court, American Journal of International Law, Vol.93. DOI azonosító: https://doi.org/10.2307/2997953

SCHERMERS, HENRY G. (2011), International Institutional Law, Brill. DOI azonosító: https://doi.org/10.1163/ej.9789004187962.i-1273

SUDAN'S OMAR AL-BASHIR A STEP CLOSER TO FACING WAR CRIMES CHARGES (2020), Al Jazzera. Elérhető: https://www-aljazeeracom.cdn.ampproject.org/v/s/www.aljazeera.com/amp/news/2020/8/2 3/sudans-omar-al-bashir-a-step-closer-to-facing-war-crimescharges? usqp $=$ mq $331 \mathrm{AQHKAFQArABIA} \% 3 \mathrm{D} \% 3 \mathrm{D} \& \mathrm{fbclid}=\mathrm{IwAR} 2 \mathrm{w}$ zxbhzp9ghPSsSZwdrroDnvjGsZdud5BvMVXiLO2TUWWTyyKtaxaY3 Lc\&amp is $\mathrm{v}=0.1 \mathrm{\# aOh}=16024906686435 \& \mathrm{csi}=1 \&$ referrer $=\mathrm{https} \% 3 \mathrm{~A}$ $\% 2 \mathrm{~F} \% 2 \mathrm{Fwww}$.google.com\&amp $\mathrm{tf}=\mathrm{Forr} \% \mathrm{C} 3 \% \mathrm{~A} 1 \mathrm{~s} \% 3 \mathrm{~A}$

SumMERS, MARK A. (2006), Immunity or Impunity? The Potential Effect of Prosecutions of State Officials for Core International Crimes in States Like the United States That Are Not Parties to the Statute of the International Criminal Court, Brooklyn Journal of International Law, Vol.1.

The United NAtions AND DARfur, FACT SHeEt. Elérhető: https://www.un.org/News/dh/infocus/sudan/fact sheet.pdf

THE WORLD FACTBOOK, AFRICA: SUDAN. Elérhető: https://www.cia.gov/library/publications/the-worldfactbook/geos/su.html

THIRD REPORT ON IMMUNITY OF STATE OFFICIALS FROM FOREIGN CRIMINAL JURISDICTION (24 May 2011) A/CN.4./646

Triffterer, OTto (2008), Commentary on the Rome Statute of the International Criminal Court, Beck Hart. DOI azonosító: https://doi.org/10.1093/jicj/mqy045

UNITED NATIONS POPULATION Division. Elérhetô: https://data.worldbank.org/indicator/SP.POP.TOTL

UNSC RESOLUTION 1564 (18 September 2004) S/RES/1564 
UNSC RESOLUTION 1593 (31 March 2005) S/RES/1593

Ventura, MANUEL J. (2015), Escape from Johannesburg? Journal of International Criminal Justice, Vol.13. DOI azonosító: https://doi.org/10.1093/jicj/mqv056

WACHMAN, RiCHARD (2007): Water Becomes the New Oil as World Runs Dry, The Guardina. Elérhető: https://www.theguardian.com/business/2007/dec/09/water.climatecha nge

WirTH, STEFFEN (2001), Immunities, Related Problems, and Article 98 of the Rome Statute, Criminal Law Forum Vol.12. DOI azonosító: https://doi.org/10.1023/A:1016191426741 